\title{
Correspondence
}

http://dx.doi.org/10.11646/phytotaxa.172.2.10

\section{Lecto- and epitypification of Stephania rotunda (Menispermaceae)}

\author{
SOVANMOLY HUL ${ }^{1, *}$, CHHAVARATH DARY ${ }^{1,2}$, FREDERIC JACQUES ${ }^{3}$, EVELYNE OLLIVIER ${ }^{2}$, SOK-SIYA \\ BUN $^{2} \&$ FLORIAN JABBOUR ${ }^{1}$ \\ ${ }^{1}$ Muséum national d'histoire naturelle, Institut de Systématique, Evolution, Biodiversité, UMR 7205 ISYEB, MNHN-CNRS-UPMC- \\ EPHE, 57 rue Cuvier CP39, 75005 Paris, France. \\ ${ }^{2}$ Laboratoire de Pharmacognosie-Ethnopharmacologie-Homéopathie, UMR-MD3, Faculté de Pharmacie, Aix-Marseille Université, 27 \\ Boulevard Jean Moulin, CS30064, 13385 Marseille cedex 5, France. \\ ${ }^{3}$ Key Laboratory of Tropical Forest Ecology, Xishuangbanna Tropical Botanical Garden, Chinese Academy of Sciences, Menglun 666303, China. \\ *Author for correspondence.Email: hul@mnhn.fr
}

The plant genus Stephania Loureiro (1790: 608-609) (Menispermaceae) comprises about 60 species distributed in tropical and subtropical Asia, tropical Africa, and Oceania (Lo et al. 2008). Species of this genus are commonly used in folk medicine for the treatment of asthma, tuberculosis, dysentery, hyperglycemia, cancer, fever, and malaria (Semwal et al. 2010). Currently, active pharmacological research is being conducted on S. rotunda Loureiro (1790: 608 ), and particularly on its tubers. This species shows in addition to antioxidant and cytotoxic activities, a significant antiplasmodial activity (Bun et al. 2009, Baghdikian et al. 2013).

Floral traits are seldom used for infrageneric determination purposes in Stephania. Rather, vegetative traits show a better taxonomical discriminating power to determine species. According to the original description of the Portuguese botanist João de Loureiro (1790), Stephania rotunda is characterized by subrounded or triangular-suborbicular peltate leaves and twining stems. No type was designated in the protologue; however Loureiro specified that the species habitat was the Cochin-Chinese forest. Two specimens collected by Loureiro, housed at the Herbarium of The Natural History Museum (BM), correspond to the type location: Loureiro s.n., BM000554372 and BM000554373 (Fig. 1A, B). The most complete specimen (the first one cited here) is now designated as the lectotype, and the other considered to be an isolectotype. Lewis L. Forman (1956: 41) noted that these specimens are ambiguous for any determination or comparison purposes. His statement needs to be qualified; the specimens are indeed poor: both are male plants, the leaves are either absent or poorly preserved, and fruits are absent (Fig. 1A, B). However, some inflorescences are present, and the overall shape of the leaves can be observed. To sum up, the assessment that $S$. rotunda's protologue is weak and the lecto- and isolectotype are not totally informative implies that the name $S$. rotunda could be wrongly applied, resulting in many specimens misidentified or identified with great uncertainty.

A search in the Web of Science ${ }^{\mathrm{TM}}$ (accessed 6 May 2014) using "Stephania rotunda" as a request finds 21 articles reporting studies of the pharmaceutical properties of plants collected and named as $S$. rotunda. Specimens identified as $S$. rotunda were included in studies investigating the phylogenetic relationships within the genus (e.g. Hoot et al. 2009), and in morphological studies (Jacques \& Bertolino 2008). It is then unquestionable that many different species of Stephania were designated with the specific epithet rotunda, with, as a corollary, the use of misidentified plants for drawing conclusions relative to the chemical properties of species that are believed to be $S$. rotunda.

We provide here a more precise diagnose of Stephania rotunda and select an epitype for this name. We looked for a species of Stephania presenting macromorphological traits that could fit those of S. rotunda, as described in the protologue and observed on the specimens collected by Loureiro in the type location. According to Gagnepain (1938: 136) and Forman (1956: 41, 1988: 385, 1991: 323), three species are morphologically comparable to $S$. rotunda: S. glabra (Roxburgh 1832: 840) Miers (1866: 14-15), S. pierrei Diels (1910: 276), and S. venosa (Blume 1825: 27) Sprengel (1827: 316). The latter species has triangular-ovate or triangular leaves, different from the triangularsuborbicular leaves found in S. rotunda as described by Loureiro (1790), and produces a red sap when no such feature was highlighted in S. rotunda's diagnosis. Stephania pierrei could be assimilated to S. rotunda. However, Diels (1910) noted that $S$. pierrei has apetalous male flowers, orbicular or suborbicular leaves, with a diameter of 2-5.5 cm, and a small tuber, which make the species inappropriate for epitypification. Additionally, some plants of $S$. pierrei have an erect habitus contrasting with the twining stems of $S$. rotunda. Stephania glabra could best fit the original description of $S$. rotund $a$ and is the most appropriate candidate for the epitypification of S. rotunda as it has triangular-suborbicular or broadly triangular-ovate leaves and a large tuber. The name $S$. glabra hence becomes synonymous with $S$. rotunda. 


\section{Acknowledgements}

We thank Germinal Rouhan and Jacques Florence (MNHN, Paris) for discussions about the nomenclatural and taxonomic decision we present in this article, Marie Bouissière and Elodie Lerat (Global Plants Initiative, MNHN, Paris), and Ranee Prakash (The National History Museum, UK) for sending us on loan the Loureiro type specimens, as well as the corresponding images.

\section{References}

Baghdikian, B., Mahiou-Leddet, V., Bory, S., Bun, S.S., Dumetre, A, Mabrouki, F., Hutter, S., Azas, N. \& Ollivier, E. (2013) New antiplasmodial alkaloids from Stephania rotunda. Journal of Ethnopharmacology 145: 381-385.

http://dx.doi.org/10.1016/j.jep.2012.10.052

Blume, C.L. von (1825) Clypea. Bijdragen tot de flora van Nederlandsch Indië. Ter Lands Drukkerij, Batavia, 1, pp. $26-28$.

Bun, S.S., Laget, M., Chea, A., Bun, H., Ollivier, E. \& Elias, R. (2009) Cytotoxic activity of alkaloids isolated from Stephania. Phytotherapy Research 23: 587-590.

http://dx.doi.org/10.1002/ptr.2617

Candolle, A.P. de (1817) Cocculus. Regni vegetabilis systema naturale. Treuttel and Würtz, Paris, 1: pp. 516-531.

Craib, W.G. (1922) Contributions to the flora of Siam. Bulletin of Miscellaneous Information, Royal Gardens, Kew 8: $225-241$. http://dx.doi.org/10.2307/4111699

Diels, F.D. (1910) Stephania Lour. In: Engler, A. (ed.) Das Pflanzenreich. von Wilhelm Engelman, Leipzig, 46 (IV, 94 ): pp. $259-283$.

Forman, L.L. (1956) The Menispermaceae of Malaysia: I. Kew Bulletin 11: 41-69. http://dx.doi.org/10.2307/4109390

Forman, L.L. (1988) A synopsis of Thai Menispermaceae. Kew Bulletin 43: 369-407. http://dx.doi.org/10.2307/4118970

Forman, L.L. (1991) Menispermaceae. In: Smitinand, T. \& Larsen, K. (eds.) Flora of Thailand, The Forest Herbarium, Royal Forest Department, Bangkok, vol. 5(3), pp. 300-365.

Gagnepain, F. (1938) Stephania rotunda. In Humbert (ed.), Supplément à la Flore générale de l'Indo-Chine, Muséum national d'histoire naturelle, Paris, vol. 1: p. 136.

Hoot, S.B., Zautke, H., Harris, D.J., Crane, P.R. \& Neves, S.S. (2009) Phylogenetic patterns in Menispermaceae based on multiple chloroplast sequence data. Systematic Botany 34: 44-56.

http://dx.doi.org/10.1600/036364409787602339

Hooker, W.J. \& Thomson, T. (1855) Stephania. Flora indica. W. Pamplin, London, pp. 195-197.

Jacques, F.M.B. \& Bertolino, P. (2008) Molecular and morphological phylogeny of Menispermaceae. Plant Systematics and Evolution 274: 83-97.

http://dx.doi.org/10.1007/s00606-008-0038-7

Lo, H.S., Chen, T., \& Gilbert, M.G. (2008) Stephania. In: Wu, C.Y. \& Raven, P.H. (eds.) Flora of China 7. Science Press, Beijing, and Missouri Botanical Garden Press, St. Louis, pp. 15-27.

Loureiro, J. de (1790) Genus VI: Stephania. Flora cochinchinensis. Ulyssupone Typis, et Expensis Academicis, pp. 608-609.

McNeill, J., Barrie, F.R., Buck, W.R., Demoulin, V., Greuter, W., Hawksworth, D.L., Herendeen, P.S., Knapp, S., Marhold, K., Prado, J., Prud'Homme van Reine, W.F., Smith, G.F., Wiersema, J.H. \& Turland, N.J. (2012) International Code of Nomenclature for Algae, Fungi and Plants (Melbourne Code). Regnum Vegetabile 154. Koeltz, Königstein, 208 pp.

Miers, J. (1866) On the Menispermaceae. 29. Stephania. The Annals and Magazine of Natural History, ser. 3, 18: 12-16.

Roxburgh, W. (1832) Cissampelos. In: Carey, W. (ed.) Flora indica. Thacker \& Co., Calcutta, and Parbury \& Co., London, 3: pp. 840842.

Semwal, D.K., Badoni, R., Semwal, R., Kothiyal, S.K., Singh, G.J.P.S. \& Rawat, U. (2010) The genus Stephania (Menispermaceae): Chemical and pharmacological perspectives. Journal of Ethnopharmacology 132: 369-383.

http://dx.doi.org/10.1016/j.jep.2010.08.047

Sprengel, C. (1827) Stephania. Systema vegetabilium sumtibus librariae dieterichianae, Gottingae, ed. 16, 4: p. 316. 